\title{
感情推論課題・心的回転課題による $\mathrm{E}-\mathrm{S}$ 尺度の検討 \\ 工藤園子 \\ (千葉大学大学院人文社会科学研究科)
}

Key words: Empathizing, Systemizing, Empathizing-Systemizing model

\section{目 的}

近年, Baron-Cohen によって，2つの心的要素から認知的 傾向を説明しようとする Empathizing-Systemizing 理論(以下 E-S 理論と表記)が提唱されている (Baron-Cohen, 2002). Empathizing とは, 他の人の感情や思考を確認し, そしてそれ らに適切な感情の反応をする働きであり, Systemizing とは, システムの動作を予測し，それをコントロールする働きであ る. Baron-Cohen ( 2003 )では, Systemizing, Empathizing がバ ランスのとれた脳のことをタイプ B, Systemizing が Empathizing よりも一定以上上回っている脳をタイプ $\mathrm{S}$, Empathizing が Systemizing よりも一定以上上回っている脳を タイプ E と分類し, 男性は女性よりも多くタイプ S の脳を持 ち，女性は男性よりも多くタイプ E の脳をもつという E-S 理 論を提唱している。

本研究では, タイプ $\mathrm{S}$ に分類される人が実際のパフォーマ ンスでも, Systemizing 能力が高いという結果を示すのか, 同 様にタイプ E の人が実際のパフォーマンスで, Empathizing 能力が高いという結果を示すのかどうかを検討する.

\section{方 法}

参加者 千葉大学の学生 124 名を対象に実験を行った。男性 が 67 名, 女性が 57 名で，平均年齢はそれぞれ 19.7 歳, 19.1 歳であった。

EQ/SQ 尺度：The Empathizing Quotient (Baron-Cohen \& Wheelwright, 2004), The Systemizing Quotient (Baron-Cohen et al., 2003)の日本語版( Wakabayashi et al., 2006)を用いた.

課題は実験室において連続的に行い，その順序はカウンタ ーバランスさせた。

心的回転課題 : コンピュータの画面の左側には物を上からみ た写真が，右側にはある方向からとった写真が提示され，上 下左右の 4 方向のうち, どちらの方向から取った写真かを十 字キーを用いてできるだけ早く判断するという課題であった. 試行数は 39 試行で, 正答の場合は 1 点, 誤答の場合には 0 点 が与えられた。

感情推論課題 : 音声を聞いて, 発話者の感情を推論するもの と, 動画を見て, 登場人物の感情を推論してもらうものの 2 種類があり，提示されるシーンを見て，またはへッドホンか ら流れる発話を聞いて，画面上に提示されている感情を表す 語が，発話者の感情や意図として適切であるか，不適切であ るかを判断し，キーボードで反応した。また，できるだけ早 く回答することを求め, 反応時間の測定を行った. 試行数は それぞれ 41 試行であり, 正答の場合には 1 点, 誤答の場合に は 0 点が与えられた。

\section{結 果}

実験参加者を質問紙(EQ/SQ)の得点に基づき, 標準化した Empathizing 得点と Systemizing 得点の差を算出し, その差が $1 \mathrm{SD}$ 以上 Empathizing 得点のみが高い人をタイプ $\mathrm{E}$, Systemizing 得点のみが高い人をタイプ $\mathrm{S}$, それ以外の人をタ イプ B として分類した. タイプ $\mathrm{E}$ に分類された参加者は 56 名, タイプ $\mathrm{S}$ は 13 名, タイプ $\mathrm{B}$ は 55 名であった.

タイプ $\mathrm{E}$ とイプ $\mathrm{S}$ のグループ間で各課題の得点に差が見 られるかどうかを検討したところ，心的回転課題においては タイプ $\mathrm{E}$ のグループよりも，タイプ $\mathrm{S}$ のグループが高い得点 をとり $(F(1,68)=13.09, p<.01)$, 感情推論課題においては夕
イプ $\mathrm{S}$ のグループよりも, タイプ $\mathrm{E}$ のグループが高い得点を とった $(F(1,68)=11.70, p<.01)$.

なお, 感情推論課題では音声を聞いて感情を推論する音声 課題においても $(F(1,68)=11.37, p<.01)$, 映像を見て感情を推 論する映像課題においても $(F(1,68)=7.63, p<.01)$, タイプ $\mathrm{S}$ と比較してタイプEのグループが高得点であった.

つまり, Systemizing 能力が関連すると思われる心的回転の 課題はタイプ $\mathrm{S}$ の人が, Empathizing 能力が関連すると思われ

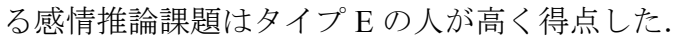

\section{考 察}

パフォーマンスによる課題の結果, 他者の感情を推論する

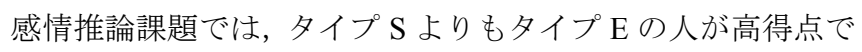
あった. E-S 理論によると, Empathizing とは, 他の人の感情 や思考を確認し, そしてそれらに適切な感情の反応をする働 きであり, Empathizing 能力と関連する感情推論課題において, タイプEの人が高得点であったことは、E-S 理論と一致する 結果といえる。同様に, 物体の認知に関する課題で, Systemizing 能力と関連寸ると考えられる心的回転課題は夕 イプ Eの人よりタイプ S の人が高得点であり, 同様に E-S 理 論を支持する結果といえる.

また，今回の実験では自己報告式の尺度により得られた得 点に基づきタイプ分けを行ったが, 先に述べたように, E-S 理論から予測されるような結果が得られた. よって, 本研究 における $\mathrm{EQ} / \mathrm{SQ}$ による分類が妥当なものであったと考えら れるが, 引き続き, 様々な課題を用いて、妥当性について検 討していく必要があると考えられる.

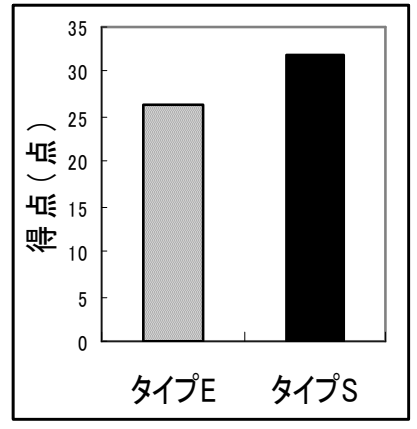

Figure1.心的回転課題得点

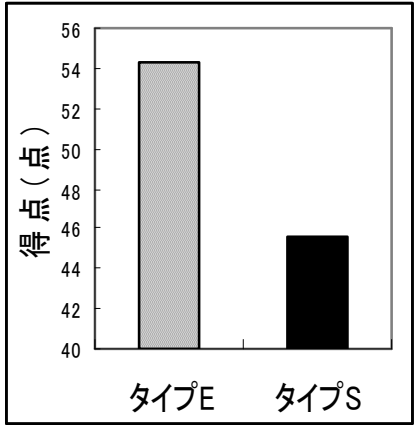

Figure2.感情推論課題得点

\section{引用文献}

Baron-Cohen, S. (2002). Trends in Cognitive Sciences, 6, 248-254.

Baron-Cohen, S., Richler, J., Bisarya, D., Gurunathan, N., \& Wheelwright, S. (2003). Philosophical Transactions of Royal Society, Series B, Special Issue on "Autism: Mind and Brain”, 358, 361-374.

Baron-Cohen, S., \& Wheelwright, S. (2004). Journal of Autism and Developmental Disorders, 34, 163-175.

Wakabayashi, A., Baron-Cohen, S., \& Wheelwright, S. (2006). Japanese Journal of Psychology, 77(3), 271-277.

(KUDOH Sonoko)

付記: 本研究で用いた感情推論課題は, 2003 年度千葉大学卒業生桑山知美さん の卒業研究の課題を基に作成した. 